\title{
Understanding the sediment routing system along the Gulf of Kachchh coast, western India: Significance of small ephemeral rivers
}

\author{
S P Prizomwala ${ }^{1,3, *}$, Nilesh Bhatt ${ }^{1}$ and N Basavaiah ${ }^{2}$ \\ ${ }^{1}$ Department of Geology, M.S. University of Baroda, Vadodara 390 002, India. \\ ${ }^{2}$ Indian Institute of Geomagnetism, Kalamboli Highway, Navi Mumbai 410 218, India. \\ ${ }^{3}$ Present address: Institute of Seismological Research, Raisan, Gandhinagar 382 009, India. \\ *Corresponding author.e-mail: siddharth_prizomwala@yahoo.co.in
}

\begin{abstract}
The present study is an attempt towards understanding the sediment routing system in the semi-arid margin of the Gulf of Kachchh, which is one of the largest macrotidal regimes in the northern Arabian Sea. Investigations based on heavy minerals, clay minerals, mineral magnetic properties and sediment geochemistry indicated that there are three major sources of sediments contributing to the Gulf of Kachchh basin: (1) Indus River, (2) Kachchh mainland coastal rivers and (3) the Saurashtra peninsular coastal rivers. The flanks of northern and southern coast of western Gulf of Kachchh show dominant signatures of Kachchh mainland/Saurashtra peninsular provenance. In contrast, the eastern Gulf of Kachchh coast bearing fine grained sediments shows dominant Indus River Provenance. Although ephemeral in nature, the small coastal rivers of Saurashtra and Kachchh contribute significant amount of sediments to the Gulf of Kachchh coastline because of their 'dryland' nature and thus they control the coarse grained sedimentation processes.
\end{abstract}

\section{Introduction}

Studies of sediment routing systems have gained considerable attention in recent times (Castelltort and Van Den Driessche 2003; Kuehl et al. 2004; Horng and Huh 2011; Jiang et al. 2011). This is because such work helps in understanding the geochemical cycling, resource management and also makes natural perturbations more predictable (MARGINS 2003). Furthermore, such studies help in appreciating the influence of terrestrial discharge on coastal and ocean processes for better understanding of the stratigraphic architecture in time and space (Goodbred 2003; MARGINS 2003; Ramaswamy et al. 2007). Unfortunately research has largely been focused on large river systems and their sediment delivery into the ocean (Goodbred 2003; Wasson 2003; Giosan et al. 2006; Yang et al. 2009). Syvitski et al. (2005) reported that the impact of small riverine systems supplying sediments to global oceans had so far been underestimated. In light of this ambiguity there is vital need to study the impact of sediment delivery by these ephemeral coastal rivers and their effect on coastal processes. The Gulf of Kachchh (figure 1; hereafter referred to as GoK) is an east-west

Keywords. Sediment routing system; ephemeral rivers; clay mineralogy; heavy minerals; mineral magnetic properties; Gulf of Kachchh. 


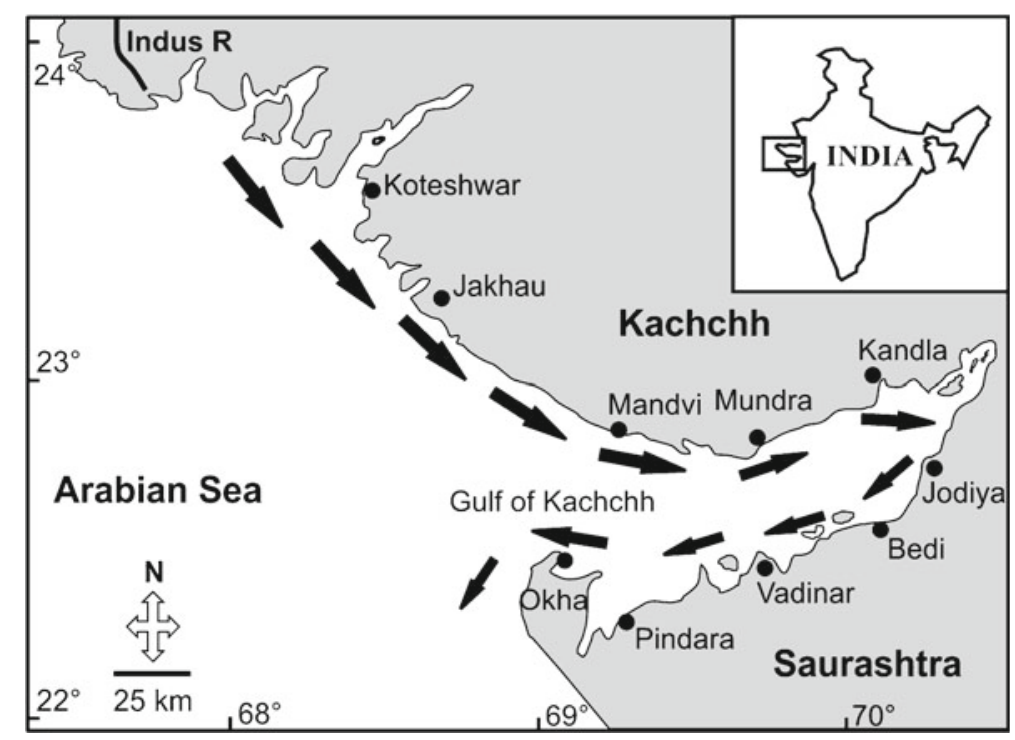

Figure 1. Present understanding of current direction in the GoK. The inset figure shows geographical location of the study area.

trending structurally controlled semi-enclosed basin, and is one of the largest macrotidal regimes in Asia with tide range of $4 \mathrm{~m}$ at its mouth and about $11 \mathrm{~m}$ in its intrinsic creeks (Ramaswamy et al. 2007). So far the GoK has attracted many workers to study its offshore dynamics in this complex macrotidal regime. There have been several studies of the region which essentially addressed its current dynamics (Shetye 1999), suspended sediment transport (Nair et al. 1982; Chauhan 1994; Kunte et al. 2003; Chauhan et al. 2004, 2006; Ramaswamy et al. 2007), sediment character of sea floor (Hashimi et al. 1978) and various sedimentation processes (Vora et al. 1987; Babu et al. 2005; Vethamony et al. 2005, 2007). However, comparatively the understanding of sedimentation along the coastline has remained 'Terra incognita', owing to the lack of work published on its geomorphology and textural attributes (Kar 1993; Maurya et al. 2008; Prizomwala et al. 2010; Shukla et al. 2010). The existing data indicate that the Indus River is the only major source of sediments to the GoK, delivering about $59 \times 10^{6}$ tons of sediments annually into the ocean (Milliman et al. 1982). Similar inference is drawn by several workers using suspended sediment concentration (SSC) and satellite imageries (Kunte et al. 2003; Chauhan et al. 2006; Ramaswamy et al. 2007). However, at the present time there are no data pertaining to the contribution made by the southerly draining rivers of the Kachchh and the rivers from the Saurashtra peninsula. The aim of the present study is to (i) characterize and evaluate the provenance and pathways of coastal sediments and (ii) ascertain the impact of sediment delivery by these rivers on the sedimentation processes along the coastline.

\section{Present understanding of the Gulf of Kachchh}

\subsection{Current circulation and physiography}

The GoK is $70 \mathrm{~km}$ wide in its western end, reducing to about $30 \mathrm{~km}$ in its central portion and $10 \mathrm{~km}$ in its eastern end, which gives it a funnelshaped geometry. The bathymetry varies significantly, with maximum depth of $50 \mathrm{~m}$ around the mouth area (western end) which reduces to $15 \mathrm{~m}$ at Kandla (central segment) and gets as shallow as $3 \mathrm{~m}$ in intrinsic creeks in the east. Also the mouth and central part of GoK hosts several shoals, which exhibit strong control on the residual currents in the gulf (Kunte et al. 2003) (figure 2). Although the GoK was considered to be a well mixed system in terms of temperature and salinity, recent studies suggest that only the central gulf is well mixed (Vethamony et al. 2007). The spatial variability in salinity in the GoK exhibits a characteristic feature of an 'inverse estuary' with higher values in eastern part compared to the western part (Vethamony et al. 2007).

Present understanding (Nair et al. 1982; Chauhan 1994; Kunte et al. 2003; Chauhan et al. 2006; Prizomwala et al. 2012, figure 1) reveals that currents enter the gulf from the western through long shore current and travel predominantly along the northern coast of GoK until they reach the central part. Because of the shallower depth and the change in orientation of the central GoK, the currents are deflected towards north and thereafter, they are reversed from the head of the gulf. From here the currents travel along the southern coast of GoK towards west and exit the mouth of GoK at Okha. 


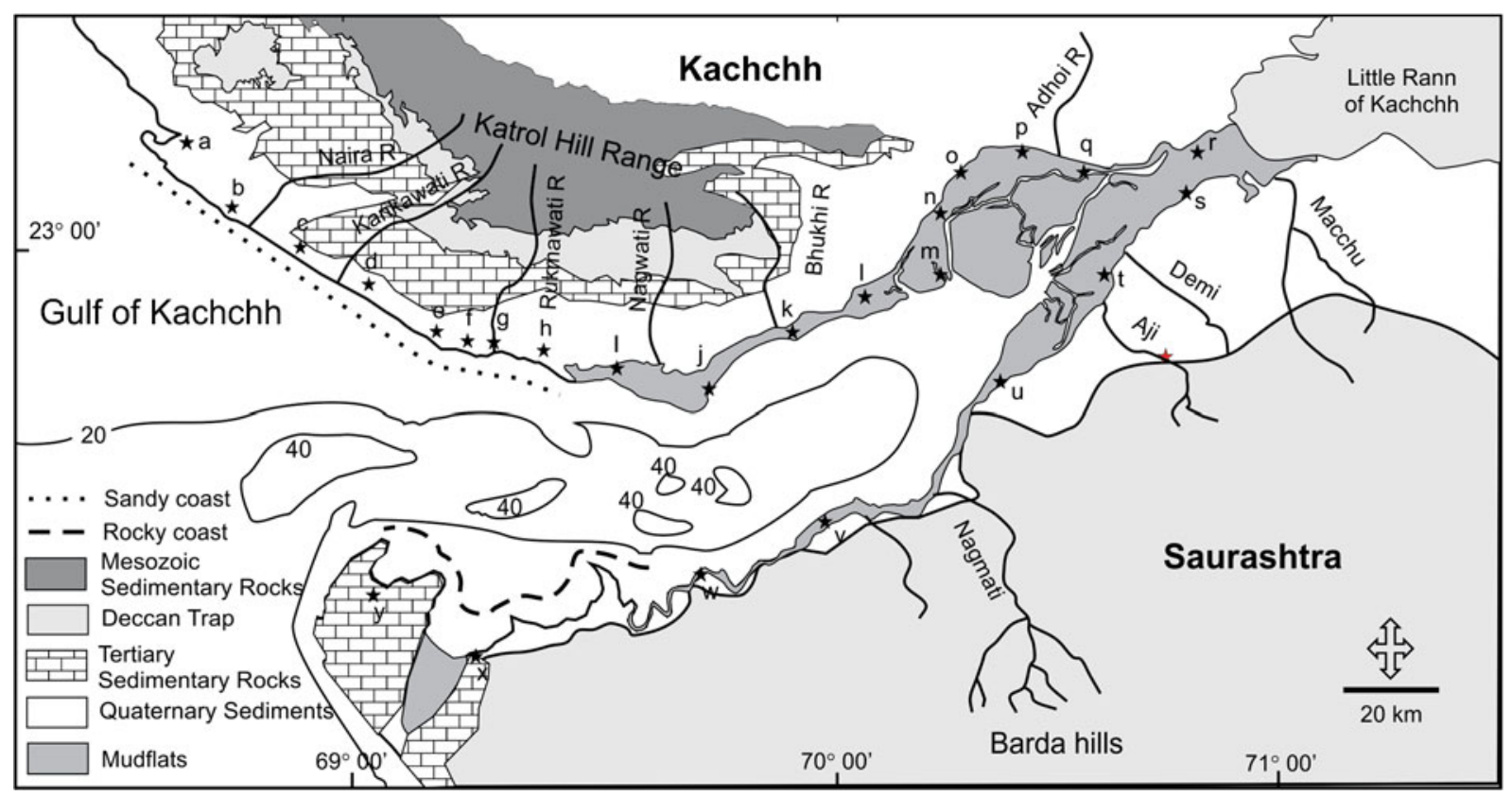

Figure 2. Map showing geological/geomorphic setup along the GoK coast along with the sampling sites and bathymetry (m) in the offshore. ((a) Jakhau, (b) Pingleshwar, (c) Khuada, (d) Chhachhi, (e) Layza Nana, (f) Mandvi Palace, (g) Mandvi, (h) Rawal Pir, (i) Navinal, (j) Mundra, (k) Bhadreshwar, (l) Jogni Mata, (m) Kandla, (n) Gandhidham, (o) Chirai, (p) Bhachau, (q) Samakhyali, (r) Surajbari A, (s) Surajbari B, (t) Navlakhi, (u) Jodiya, (v) Bedi, (w) Vadinar, (x) Pindara and (y) Okha) (modified after Biswas 1993).

\subsection{Fluvial systems around the Gulf of Kachchh}

The southern flowing rivers from the Kachchh mainland and Saurashtra peninsula which drain into the GoK are the Naira, Kankawati, Rukmavati, Nagwati, Bhukhi, Aji, Machchhu, Demi and Adhoi (figure 2). The Indus River is the only major perennial river in the region, although it does not directly drain into the GoK, it is known to contribute sediments through long shore currents from the mouth of the river (Nair et al. 1982; Ramaswamy et al. 2007).

Rivers emanating from the Kachchh mainland drain through Mesozoic rocks in the north comprising sandstones and shale outcropping in the Katrol hill range and towards the south they cut across the Deccan Trap basalts and Tertiary limestone, shale and sandstone (Biswas 1993, figure 2). Similarly, the coastal fluvial systems of the Saurashtra peninsula rise from the Barda hills, which are composed of magmatic rocks like granophyres, feldspar porphyries and Deccan Trap Formation and traverse predominantly through basalts and laterites. Tertiary limestone and clay beds are present near the coastline where these fluvial systems debouch into the GoK.

\subsection{Sediments and geomorphology of Gulf of Kachchh}

The coastal geomorphic setup of the GoK exhibits two distinct zones. The western part is dominantly the sandy landforms like beaches, berm plain, beach ridges and coastal dunes that eventually merge into a monotonous wide mudflat zone, which covers a vast area of around $1500 \mathrm{~km}^{2}$ (Prizomwala et al. 2010; Shukla et al. 2010). The central narrow part, which acts as a transition zone contains an admixture of sandy and muddy sediments (Prizomwala et al. 2010; Shukla et al. 2010). There have been a number of studies of suspended sediments from gulf waters for clay mineralogy and geochemical compositions (Nair et al. 1982; Chauhan et al. 2004, 2006; Ramaswamy et al. 2007), but their significance is limited to suspended sediments dynamics only. The sediment variability of the sea bottom of GoK was studied by Hashimi et al. (1978) who showed that the mouth of GoK is marked by rocky outcrops, whereas the inner GoK (i.e., eastwards) is mantled by a thick column of fine grained sediments before being dissected into creeks.

\section{Methodology}

\subsection{Granulometric analysis}

For the present study, samples were collected at 25 locations from the intertidal region covering the entire GoK coastline (figure 2). Three samples were collected from each location and grain size analysis 
was carried out using conventional mechanical sieving and pipette methods following Folk (1974). The mechanical sieving was done at half-phi interval $(n=21)$ and different statistical variables namely mean, standard deviation, kurtosis were derived. The pipette method was used for samples which were muddier in content $(n=54)$ and sand-silt-clay percentage was calculated.

\subsection{Heavy mineral analysis}

A total of 54 samples were analyzed for heavy mineral analysis and heavy minerals were separated from medium $(0.5-0.25 \mathrm{~mm})$ and fine sand $(0.25-$ $0.063 \mathrm{~mm}$ ) fractions using heavy liquid (Bromoform, specific gravity of $2.89 \mathrm{~g} / \mathrm{cm}^{3}$ at $20^{\circ} \mathrm{C}$ ). The identification of heavy minerals was done under binocular microscope and point counted to 250 grains (Mange and Maurer 1991).

\subsection{Environmental magnetism studies}

Sixty samples of two different sizes, i.e., $>63 \mu \mathrm{m}$ (sand fraction) and $<63 \mu \mathrm{m}$ (silt + clay fraction) were investigated for mineral magnetic properties. The analysis was carried out in separate fractions in order to minimise the grain size effect in magnetic measurements. Susceptibility $(\chi)$ was measured using a MFK1-FA multifunction frequency Kappabridge which had a sensitivity of $10^{-6}$ SI. To detect superparamagnetic (SP) particles, frequency dependent susceptibility $\left(\chi_{\mathrm{fd}} \%\right)$ was obtained using the expression $\left(\chi_{\mathrm{LF}}-\chi_{\mathrm{HF}}\right) /$ $\chi_{\mathrm{LF}} \times 100$ (Worm 1998), where $\chi_{\mathrm{LF}}$ is magnetic susceptibility at low frequency $(976 \mathrm{~Hz})$ and $\chi_{\mathrm{HF}}$ is susceptibility at high frequency $(15,616 \mathrm{~Hz})$. ARM was imparted in a $100 \mathrm{mT}$ alternating field and a $0.05 \mathrm{mT}$ bias field using a Molspin AF demagnetizer. ARM is expressed as ARM per unit steady field, $\chi_{\mathrm{arm}}$. All remanant magnetizations of ARMs and IRMs were measured using a Molspin Spinner Magnetometer. The IRM was imparted at forward fields (mT) of 20 and 1000 (= Saturation IRM (SIRM)) and backward fields (mT) of 20, 40, 60, 100 and 300 using the Molspin Pulse Magnetizer. The S-ratio, simplified here as ratio of IRM $_{-0.3 \mathrm{~T}} / \mathrm{SIRM}$, is used as an indicator of the relative contributions of magnetic mineralogy in terms of ferrimagnetic and antiferromagnetic components (Maher et al. 2009).

\subsection{Clay mineralogy}

Oriented clay slides were prepared using $<2 \mu \mathrm{m}$ fraction for 50 samples following Stoke's law for $\mathrm{X}$-ray diffraction analysis at the Department of
Geology, the M.S. University of Baroda, India. Each clay slide was scanned from $2^{\circ}$ to $30^{\circ} 2 \theta$ using nickel-filtered $\mathrm{Cu} \mathrm{K} \alpha$ radiation on Rigaku's Ultima II model. Mineral identification was carried out using basal reflection peaks (Biscaye 1965; Petschick et al. 1996). Specimens were exposed to glycolation treatment (using ethylene glycol) for $12 \mathrm{hrs}$ at room temperature and again analyzed with same instrumental setting. All samples were scanned from $24^{\circ}$ to $26^{\circ} 2 \theta$ at $1 / 2^{\circ} 2 \theta \mathrm{min}^{-1}$ to differentiate kaolinite and chlorite.

\subsection{Geochemical analysis}

Fifty samples from all the locations were studied for elemental concentrations of $\mathrm{Ti}, \mathrm{Al}$ and $\mathrm{Fe}$ using X-ray fluoresence (XRF) (SPECTRO XEPOS) at Indian Institute of Geomagnetism, Navi Mumbai, India. About $1 \mathrm{gm}$ of $<63 \mu \mathrm{m}$ fraction was utilized for this purpose. The accuracy of measurements was checked against the GBW-07401 Geochemical Standard Reference Soil Sample and the precision was better than $2 \%$.

\section{Results}

\subsection{Granulometric analysis}

Sand-silt-clay content along different segments of the GoK coast is shown in figure 3 . Prizomwala et al. (2013) along the sandy segment of the northern coast shows that the mean grain size of sediments ranges between $0.71 \mathrm{~mm}$ to $0.125 \mathrm{~mm}$. In the extreme west at Pingleshwar, the grain size is medium sand class (0.71$0.5 \mathrm{~mm}$ ) whereas towards the east at Rawal Pir, grain size becomes finer $(0.5-0.25 \mathrm{~mm})$. Silty sediments dominate at Jakhau towards the west with $15 \%$ sand, $73 \%$ silt and $12 \%$ clay. The mudflat dominated coast starts from Modwa and becomes wider towards the east. The increase in standard deviation values from Layza Nana towards the east and presence of both sandy as well as muddy landforms between Layza Nana and Mundra at the central part of the gulf suggests that the area acts as a transitional zone within the GoK (Prizomwala et al. 2013). The inner GoK coast towards the east has wide mudflats and variable sand content between 2 and $20 \%$. The mudflats are mostly silty but, in extreme inner gulf the clay content increases to more than 50\% around Samakhyali (figure 3). The increase in sand content along the southern coast of the inner GoK is caused by the presence of a few ephemeral rivers in the vicinity namely, Aji, Machchhu and Demi. The southern mouth of the GoK shows an increase in silt content with a 


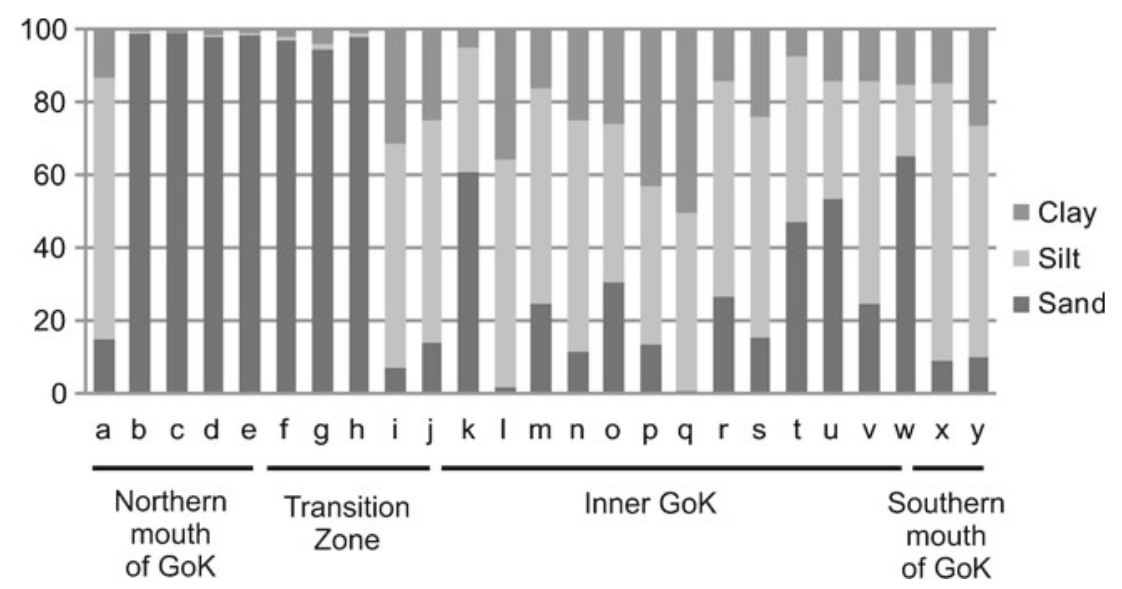

Figure 3. Grain size analysis of surface sediments: major stations along the GoK coast.

Table 1. Distribution of heavy minerals in intertidal microenvironment along the northern sandy segment of GoK coast after Prizomwala et al. (2013).

\begin{tabular}{|c|c|c|c|c|c|c|c|c|}
\hline Location & $\begin{array}{c}\text { Tourmaline } \\
(\%)\end{array}$ & $\begin{array}{c}\text { Staurolite } \\
(\%)\end{array}$ & $\begin{array}{l}\text { Zircon } \\
(\%)\end{array}$ & $\begin{array}{c}\text { Sillimanite } \\
(\%)\end{array}$ & $\begin{array}{c}\text { Biotite } \\
(\%)\end{array}$ & $\begin{array}{c}\text { Muscovite } \\
(\%)\end{array}$ & $\begin{array}{c}\text { Diopsidic } \\
\text { clinopyroxene }(\%)\end{array}$ & $\begin{array}{c}\text { Opaques } \\
(\%)\end{array}$ \\
\hline Pingleshwar (P) & 12 & 10 & 4 & 2 & 19 & 14 & 0 & 39 \\
\hline Khuada (K) & 12 & 8 & 5 & 1 & 17 & 10 & 0 & 48 \\
\hline Chhachhi (C) & 3 & 3 & 1 & 0 & 15 & 8 & 10 & 60 \\
\hline Layza Nana (L) & 3 & 2 & 1 & 1 & 14 & 9 & 16 & 54 \\
\hline Mandvi Palace (M) & 2 & 1 & 0 & 0 & 15 & 9 & 18 & 55 \\
\hline Rawal Pir (R) & 2 & 0 & 0 & 0 & 12 & 7 & 21 & 58 \\
\hline
\end{tabular}

decrease in the amount of clay but an increase in the amount of sandy sediments towards the west (i.e., Okha and Pindara).

\subsection{Heavy mineral analysis}

Heavy mineral assemblages are used as an indicator of sediment provenance (Pettijohn et al. 1987; Nechaev and Isphording 1993; Yang et al. 2003; Garzanti et al. 2005; Garzanti and Ando 2007). Heavy mineral assemblages have recently been used and show potential for inferring the sediment sources in the GoK (Prizomwala et al. 2013).

The medium and fine sand fractions of intertidal sediments show the highest concentrations of heavy minerals in the western part of the northern sandy segment of the GoK. The heavy mineral concentration decreases towards the east in the inner GoK. This can be attributed to the reduction in sand content and energy conditions prevalent in the mudflats of the inner GoK. The sands of the inner GoK hosted by wide mudflats had negligible or complete absence of heavy minerals, whereas the sands of southern coast of the inner GoK had some heavy minerals (i.e., mostly diopsidic clinopyroxenes and magnetite) predominantly derived from the Deccan Trap (basalt) terrain of Saurashtra peninsula. The heavy minerals present in the sand fraction of the northern sandy segment are shown in table 1 , which demonstrates three major source end-members supplying sediments to this coastline, namely: (1) Granitic-Gneissic source (tourmalinezircon-biotite-muscovite), (2) medium to highgrade metamorphic source (staurolite-sillimanite) and (3) Deccan Trap basalt and its derivatives source (diopsidic clinopyroxene-magnetite). Changes in provenance/source shifts can be appreciated in figure 4, which shows dominance of the granitic-gneissic source in western end of the gulf and progressive increase of Deccan Trap source eastwards. This source shift may be interpreted as reflecting the influence of the numerous Kachchh mainland rivers debouching dominantly the Deccan Trap derived sediments along this segment of GoK (figure 2). Because of the eastward current direction the sediments delivered by these coastal rivers are redistributed along the coastline eastwards and hence, the Deccan Trap source progressively dominates from Chhachhi (figure 4).

The presence of mica minerals (muscovite and biotite) has a special significance in the GoK, owing to its characteristic sediment transport mechanism (Nair et al. 1982; Prizomwala et al. 2012). Figure 5 shows the spatial distribution of mica minerals in the intertidal sediments of the GoK coast. 


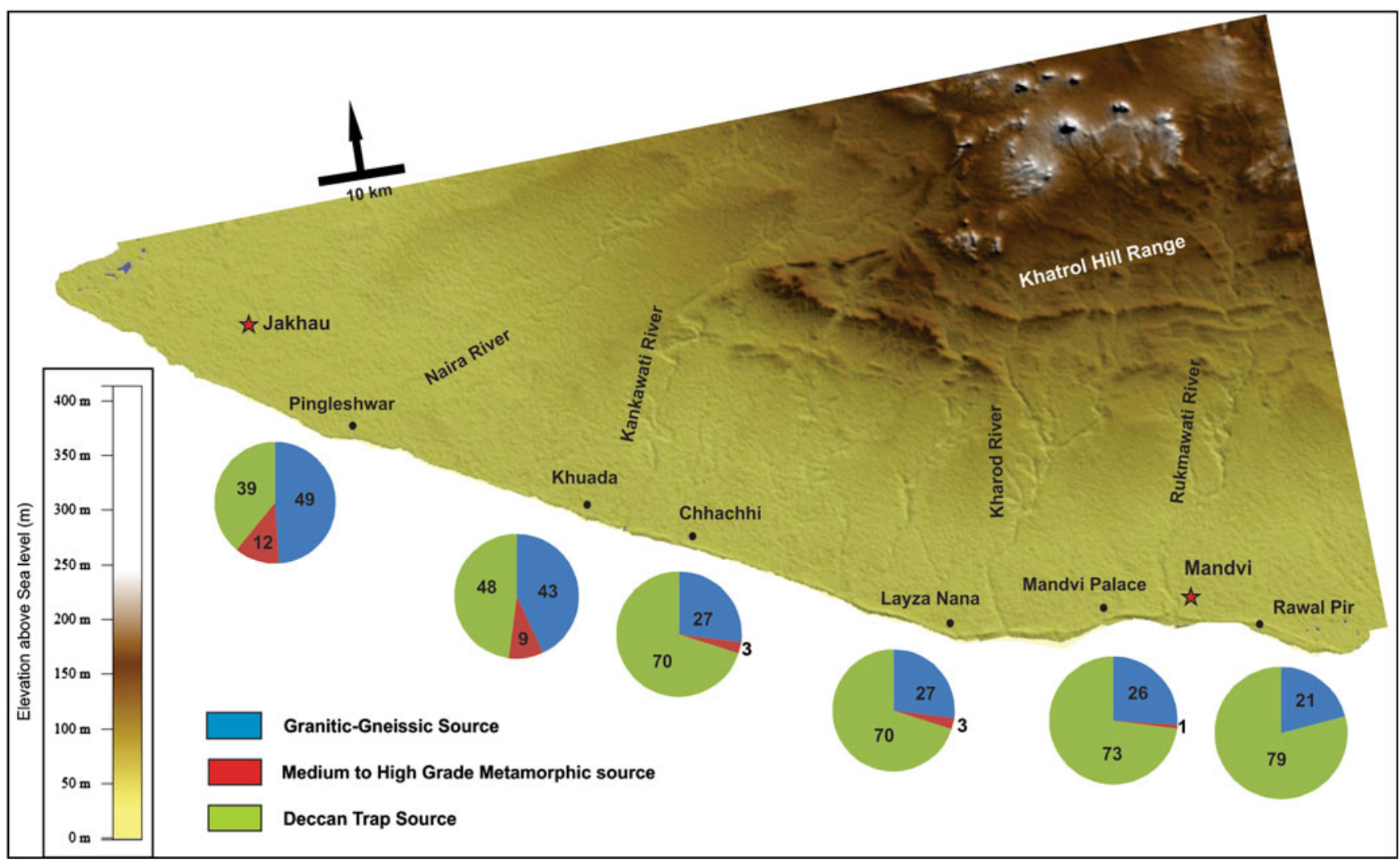

Figure 4. Provenance shift on the basis of heavy mineral analysis of $>63 \mu \mathrm{m}$ fraction along the northern sandy segment of the GoK coast. Note that the vertical colour scale shows elevation (after Prizomwala et al. 2013).

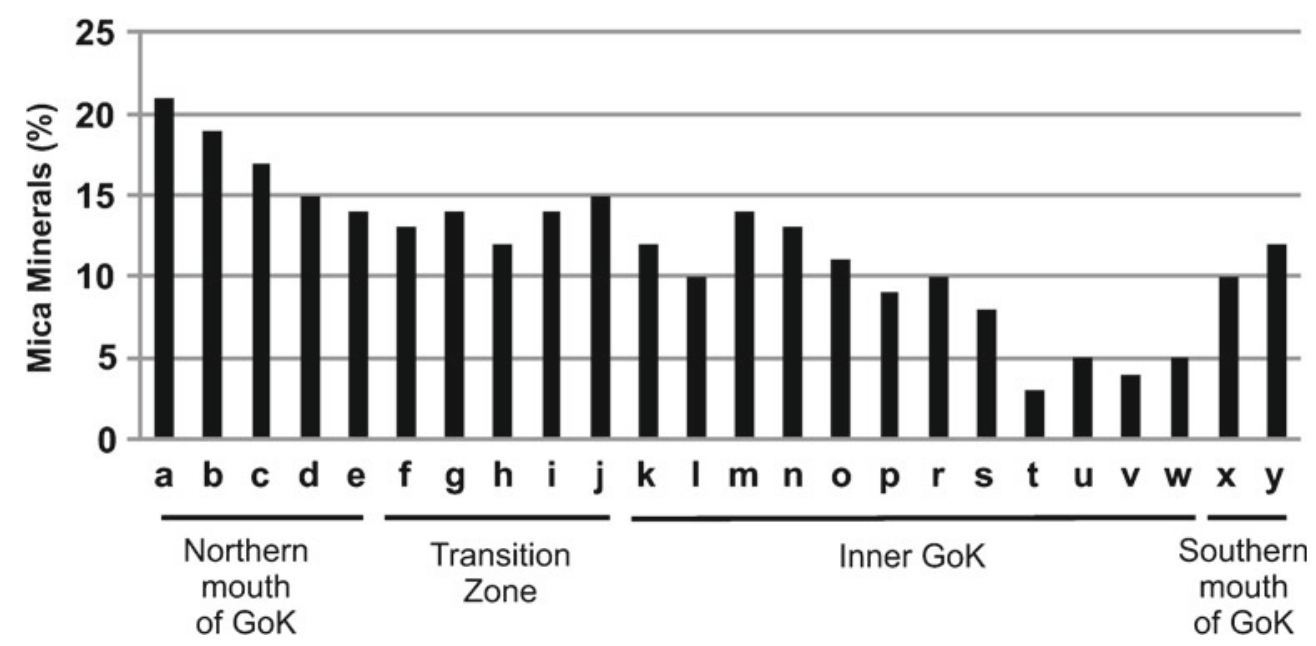

Figure 5. Mica mineral distribution in surface sediments along the GoK coast (after Prizomwala et al. 2012).

Prizomwala et al. (2012) observed the higher concentrations towards west in the northern sandy segment and progressive reduction towards the east (figure 5). Mica minerals are sourced from the Indus River, which drains from the Himalayas and are redistributed along the GoK coast via the alongshore currents (Garzanti et al. 2005; Prizomwala et al. 2012). In this scenario as the distance from the source (i.e., the Indus River) increases the concentration of mica minerals would be expected to reduce. However, the sand fraction of mudflats of the inner GoK towards east also hosts considerably higher amounts of mica minerals because of the coastal processes of sediment sorting and redistribution. The mudflats acts as sub-sinks for the suspended fraction and hence the residence of mica minerals is higher in them, which leads to their increased concentration in sand 
fraction of mudflats. The southern coast of the inner GoK shows an anomalous decrease in the concentrations of mica minerals probably because of the input from the Saurashtra rivers draining through Deccan Trap basalt source. Further along the sediment transport path a sharp increase at the westernmost end of the southern coast at the mouth of GoK is also interesting to note, as it is supportive evidence to claim that the currents travel directly from north across the mouth of the GoK (Prizomwala et al. 2012).

\subsection{Environmental magnetism}

Mineral magnetic measurements have been identified as a suitable tool for determining sediment provenance (Oldfield and Yu 1994; Liu et al. 2010; Prizomwala et al. 2013) and sediment transport pathways (Lepland and Stevens 1996; Maher et al. 2009; Wang et al. 2010). The relationships between different magnetic parameters such as the susceptibility $(\chi)$, frequency dependent susceptibility $\left(\chi_{\mathrm{fd}} \%\right)$, anhysteretic remanent magnetization (ARM) and isothermal remanent magnetization (IRM) is a function of the concentration, type and grain-size of magnetic minerals present in the sediments (Maher et al. 2009; Basavaiah 2011).

Changes in $\chi_{\mathrm{LF}}, \chi_{\mathrm{arm}}$ and SIRM generally indicate variations in the content of ferrimagnetic matter (e.g., magnetite or titanomagnetite), although they also respond to magnetic grain size variations and changes in magnetic mineralogy. For example, the ferrimagnetic minerals have a significantly higher magnetic susceptibility $\left(+10^{-2}\right)$ than most other common minerals $\left(-10^{-6}\right.$ to $\left.+10^{-6}\right)$. Consequently, the $\chi_{\mathrm{LF}}$ can be a good indicator of magnetic concentrations of samples (Maher et al. 2009), whereas $\chi_{\text {arm }}$ indicates concentration of stable single domain ferrimagnetic minerals and SIRM is a good indicator of concentration of saturated ferrimagnetic minerals (Maher et al. 2009). Here the magnetic measurements of $\chi_{\mathrm{LF}}, \chi_{\mathrm{arm}}$ and SIRM of samples are used to distinguish between different source areas of terrigenous sediments to the GoK.

\subsubsection{Mineral magnetic analysis of $>63 \mu \mathrm{m}$ fraction}

The sand $(>63 \mu \mathrm{m})$ fraction of mouth of northern sandy coast of GoK towards west has relatively less concentrations of magnetic minerals $\left(\chi_{\mathrm{LF}}=65\right.$ to $\left.300\left(\times 10^{-7} \mathrm{~m}^{3} \mathrm{~kg}^{-1}\right)\right)$ compared to rest of the coastline. The magnetic mineral concentration increases from Chhachhi towards the east, this is because of the sediment contribution from the several coastal ephemeral rivers draining through Deccan Trap basalts of the Kachchh mainland and debouching into this segment of the GoK (figure 6). The segment between Chhachhi and Mundra (i.e., transition zone) has intermediate magnetic mineral concentrations (400 to $1100\left(\times 10^{-7} \mathrm{~m}^{3} \mathrm{~kg}^{-1}\right)$ ), barring the station Mandvi which has higher magnetic mineral concentrations $\left(2400 \times 10^{-7} \mathrm{~m}^{3} \mathrm{~kg}^{-1}\right)$ as it is an estuarine zone. The sand fraction in the mudflats of the inner GoK towards the east has low to intermediate magnetic mineral concentrations (280 to $\left.2700\left(\times 10^{-7} \mathrm{~m}^{3} \mathrm{~kg}^{-1}\right)\right)$ along the northern coast and an increase in mineral magnetic concentrations (3100 to $\left.7500\left(\times 10^{-7} \mathrm{~m}^{3} \mathrm{~kg}^{-1}\right)\right)$ along the southern coast. Towards the west the southern coast of the mouth of the GoK shows anomalously low concentration of magnetic minerals (57 to $\left.70\left(\times 10^{-7} \mathrm{~m}^{3} \mathrm{~kg}^{-1}\right)\right)$, which may be caused by the presence of carbonate sands drained from the Tertiary Dwarka and Gaj formations, which consist of limestones and are diamagnetic. $\chi_{\text {arm }}$ values are higher in the sandy segment of the northern coast of GoK (0.5 and $\left.1.7\left(\times 10^{-5} \mathrm{Am}^{2} \mathrm{~kg}^{-1}\right)\right)$ going towards the west, and are very low in the mudflat segment $\left(0.05\right.$ to $\left.0.5\left(\times 10^{-5} \mathrm{Am}^{2} \mathrm{~kg}^{-1}\right)\right)$ towards the east, barring the southern coast of the inner GoK, where $\chi_{\text {arm }}$ shows an abrupt increase (0.5 to $\left.2.3\left(\times 10^{-5} \mathrm{Am}^{2} \mathrm{~kg}^{-1}\right)\right)$. The southern mouth of the GoK towards west again shows low $\chi_{\text {arm }}$ values $\left(0.04 \times 10^{-5} \mathrm{Am}^{2} \mathrm{~kg}^{-1}\right) \cdot \chi_{\mathrm{fd}} \%$ for all the stations was below $5 \%$, except for stations Pingleshwar, Kandla and Okha, indicating negligible contributions from superparamagnetic grains. The mouth of the northern and southern coast of the GoK towards the west showed higher values of $\chi_{\text {arm }} / \chi_{\text {LF }}$ indicating more stable single domain size range of magnetic grains compared to the inner GoK located towards the east.

The S-ratio, which depicts the dominant mineralogy remains $>0.90$ for the entire coastline, except for sites Pingleshwar and Khuada in the northern sandy segment in the west, and sites Chirai and Surajbari in the east where values dropped to 0.85 . The southern mouth of the GoK also showed Sratio values of 0.72 , similar to northern mouth of GoK. As a result, it is evident from above mentioned parameters that the magnetic mineral concentration in the $>63 \mu \mathrm{m}$ fraction of sediments is dominantly supplied by the ephemeral coastal rivers of Kachchh and Saurashtra.

\subsubsection{Mineral magnetic analysis of $<63 \mu m$ fraction}

The magnetic mineral concentration in the $<63 \mu \mathrm{m}$ sediment fraction (figure 6) showed enrichment of magnetic minerals in the transition zone segment at Mundra $\left(1120 \times 10^{-7} \mathrm{~m}^{3} \mathrm{~kg}^{-1}\right)$ and Navinal 
a) Magnetic concentration

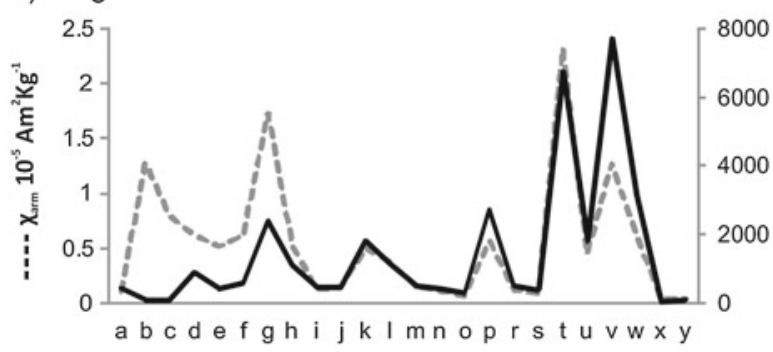

b) Magnetic grainsize

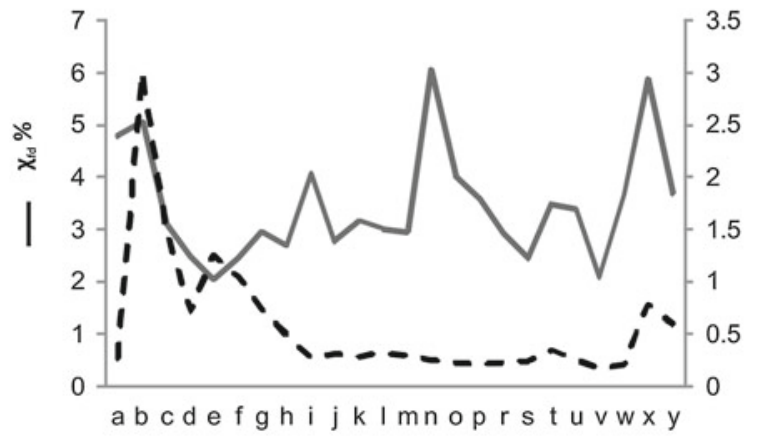

c) Magnetic mineralogy

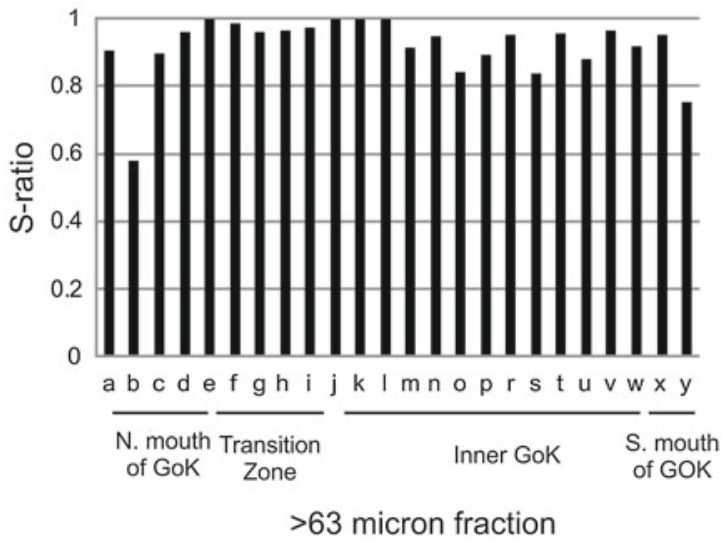

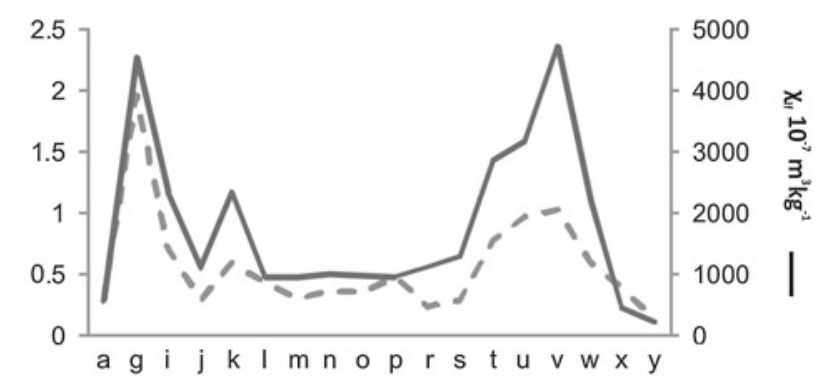
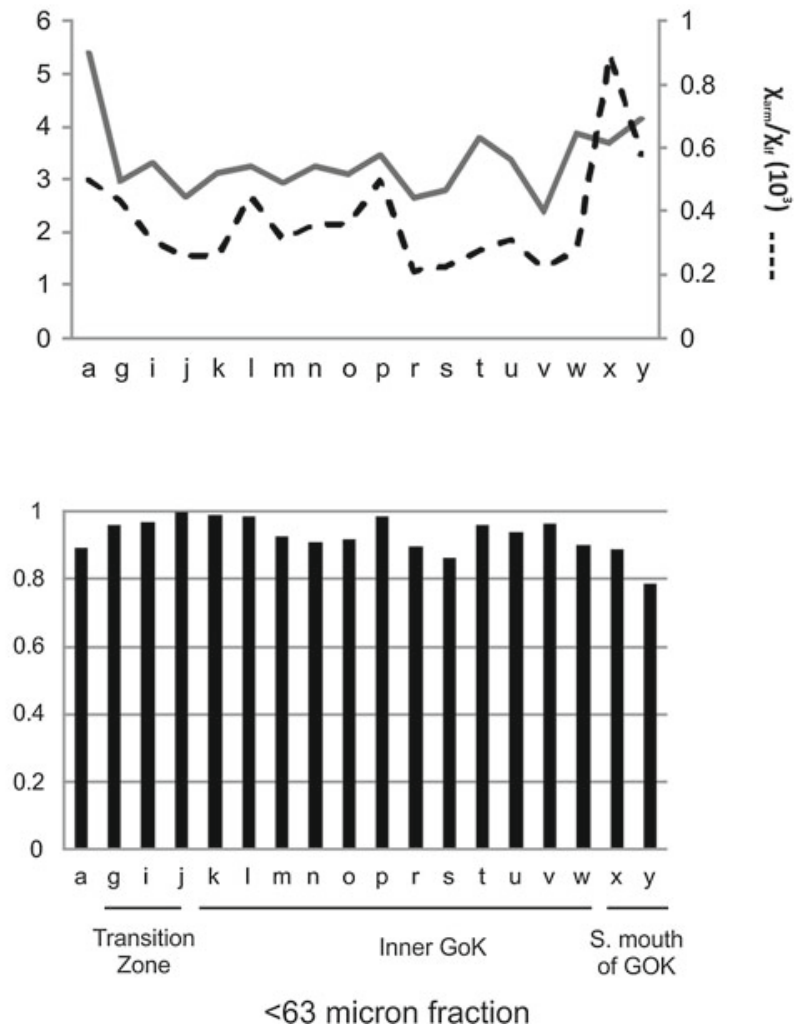

Figure 6. Mineral magnetic properties showing magnetic concentration, grain size and mineralogy in $>63 \mu \mathrm{m}$ and $<63 \mu \mathrm{m}$ fraction of surface sediment of the GoK coast.

$\left(2300 \times 10^{-7} \mathrm{~m}^{3} \mathrm{~kg}^{-1}\right)$ in the central GoK, whereas magnetic mineral concentration remained intermediate in the eastern part of the northern coastline of the inner GoK mudflats (900 to $1200\left(\times 10^{-7}\right.$ $\left.\mathrm{m}^{3} \mathrm{~kg}^{-1}\right)$ ). Magnetic mineral concentrations show a sharp increase along the southern coast (2100 to $\left.4700\left(\times 10^{-7} \mathrm{~m}^{3} \mathrm{~kg}^{-1}\right)\right)$. The mouth of southern coast towards the west shows a sharp drop in magnetic mineral concentrations (220 to 430 $\left.\left(\times 10^{-7} \mathrm{~m}^{3} \mathrm{~kg}^{-1}\right)\right)$, similar to the western sites of the northern coast of the GoK. $\chi_{\text {arm }}$ values range between 0.5 and 2 and show similar trends as the magnetic susceptibility for the entire coastline. The ratio $\chi_{\mathrm{arm}} / \chi_{\mathrm{LF}}$ shows similar trend as in the $>63 \mu \mathrm{m}$ fraction and has higher values in the west at the mouth of the northern and southern coasts, indicating more stable single domain magnetic grain size. The $\chi_{\mathrm{fd}} \%$ remains $<5 \%$ and hence the contribution from the superparamagnetic grains may be insignificant. S-ratio values are mostly $>0.90$ for all sites barring the westernmost sites of the northern and southern sides of the mouth of the GoK and the Surajbari in east, demonstrating that the magnetic mineralogy is relatively homogeneous dominated by magnetite or titanomagnetite.

\subsection{Clay mineralogy}

Clay mineralogy is as an established proxy for provenance studies in the Arabian Sea and western margin of India (Kolla et al. 1976; Chauhan 1994; Rao and Rao 1995; Kessarkar et al. 2003; Alizai et al. 2012; Limmer et al. 2012a).

The clay mineralogy of the $<2 \mu \mathrm{m}$ fraction showed that the dominant mineral present were illite, chlorite, smectite and kaolinite. The 
concentration of illite varied from 25 to $52 \%$, whereas chlorite varied from 11 to $22 \%$ and the illite-chlorite assemblage shows a clear trend of higher concentration along northwestern coast and reduced concentrations eastwards into the inner GoK. The smectite concentrations vary from 7 to $54 \%$, whereas kaolinite concentrations vary from 5 to $25 \%$. The smectite-kaolinite assemblage dominates along the southern coast of the inner GoK in the east which hosts the mudflats. Illite and chlorite are major erosion products of the Himalayan rivers (in this case Indus River) owing to the predominant physical weathering and cold-arid climate (Kolla et al. 1976; Kessarkar et al. 2003; Ramaswamy et al. 2007) whereas, smectite is the major weathering product of the Deccan Trap basalts (Rao and Rao 1995; Kessarkar et al. 2003) that outcrop in Kachchh and Saurashtra. However, some recent studies reported that the floodplain sediments from River Indus and the sediments from the western Indus shelf show illite-smectite dominant clay mineral assemblage (Alizai et al. 2012; Limmer et al. 2012a). These anomalous higher amounts of smectite in the floodplain sediments was explained as increased pedogenic smectite due to enhanced chemical weathering owing to lack of fluvial transport (Alizai et al. 2012), whereas the smectite in shelf region were linked to longshore drift by Bela ophiolite (Limmer et al. 2012a).

Interestingly the adjoining landmasses of Kachchh and Saurashtra have sources of smectite in the form of the Deccan Trap basalt province (Prizomwala et al. in press). Henceforth we use the ratio of (illite + chlorite) to (smectite + kaolinite) to distinguish between the Indus-derived detrital sediments and hinterland derived detrital sediments. The (illite + chlorite) to (smectite + kaolinite) ratio shows values of $>2$ near the northwestern coast of the GoK that reduces towards the east, where it drops to $0.5-1.0$ and again peaks to values $>2.0$ along the southern coast near the mouth of GoK (figure 7). This trend clearly shows the provenance shifts between proximal (i.e., Kachchh and Saurashtra) and the distal sources (i.e., River Indus) contributing to this catchment in fine grained sedimentation.

\subsection{Sediment geochemistry}

The concentration of various elements in the sediments is a function of the different mineral assemblages present therein, which is due to their source rock characteristics, transport processes and degree of chemical weathering. The spatial distribution of $\mathrm{Al}, \mathrm{Fe}$ and $\mathrm{Ti}$ along the entire GoK coastline is shown in figure 7. The concentration of $\mathrm{Al}$ is highest at Jakhau towards the west and reduces in the northern sandy segment of the GoK. Al again increases and dominates in the inner gulf mudflat towards east with values near to $15 \%$. The spatial distribution of Al-concentration suggests its affinity to clay minerals (i.e., enriched in mudflats). In contrast, Fe concentration is highest in the sandy segment of the northern coast $(\sim 19 \%)$ but reduces in the inner gulf mudflats $(\sim 5 \%)$ and increases again along the southern coast $(\sim 12 \%)$, indicating that magnetic minerals are its major influences.

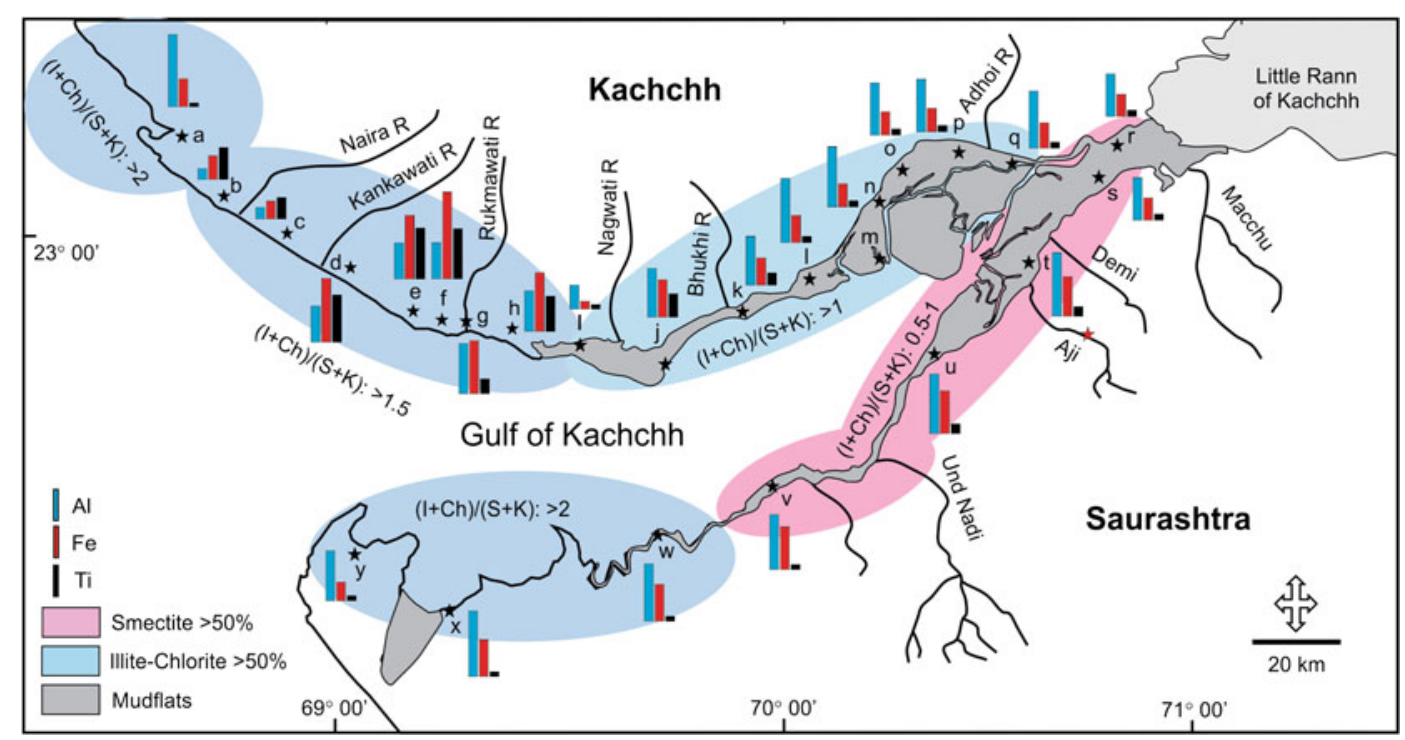

Figure 7. Spatial distribution of clay mineral (illite + chlorite)/( smectite + kaolinite) ratio and Al-Ti-Fe concentration in the surface sediments of GoK coast. 
The Ti concentration is highest in the sandy segment of the northern coast of the GoK but, has negligible concentration in the sediments of the mudflats of inner gulf and southern coast of the GoK, indicating its source could mostly be the Kachchh mainland fluvial system.

The concentrations of $\mathrm{Rb}$ and ratios of $\mathrm{Rb} / \mathrm{Ga}$ have been used by several workers to elucidate the provenance of sediment in the Arabian Sea, because $\mathrm{Rb}$ concentrations are higher in potassium-rich illite-dominated sediments of the Indus River compared to the smectite-rich Deccan Trap material from the Kachchh mainland (Ramaswamy et al. 2007; Prizomwala et al. in press). Staubwasser and Sirocko (2001) also used $\mathrm{Rb} / \mathrm{Ga}$ as an indicator of Indus derived sediments. Figure 8 shows values of $\mathrm{Rb}$ and $\mathrm{Rb} / \mathrm{Ga}$ in intertidal sediments of the GoK coast and some previously published values from offshore suspended sediments. The western part of the Kachchh coast shows similar values as reported by Ahmad et al. (1998) for bed sediments of the River Indus. The northern sandy coast of GoK shows very low $R b$ values and low $\mathrm{Rb} / \mathrm{Ga}$ ratio indicating their source predominantly being Kachchh mainland rivers, which contain lower concentrations of $\mathrm{Rb}$ and lower values of $\mathrm{Rb} / \mathrm{Ga}$. The inner GoK mudflats show enrichment in $\mathrm{Rb}$ and $\mathrm{Rb} / \mathrm{Ga}$ values (98, 6.28 and 94, 5.49) along northern and southern coastline, and are even more enriched in the mouth of the southern coast of the GoK $(148,7.14)$. This is again supportive of the fact that the Indus River is a major end-member contributing to this coastline in suspended sediment.

\section{Discussion}

As shown by figure 1 and the present understanding of current dynamics (Nair et al. 1982; Chauhan 1994; Kunte et al. 2003; Chauhan et al. 2006; Prizomwala et al. 2012) the sediments are believed to enter the gulf mouth from the northwest and travel along the GoK coastline before exiting from southwestern part of the mouth. In this scenario the concentration of Indus River sediment (within sand and heavy mineral content) should be highest at the northwestern end and should subsequently reduce along the rest of the pathway towards east. In contrast, the clay fraction should show predominant signatures of Indus River provenance along the entire route owing to the great magnitude of sediment flux being released from the Indus River. In contrast, our grain size and heavy mineral data, clay mineralogy, mineral magnetic studies (on both size fractions) and geochemistry of intertidal sediments do not reflect this, but show three major provenance signatures along the GoK coastline (figure 9). Three major end-members which have been identified are (a) Indus River, (b) Kachchh mainland coastal ephemeral rivers and (c) Saurashtra peninsular coastal ephemeral rivers, which exhibit distinct clay mineral, geochemical and magnetic properties.

\subsection{River Indus provenance}

The River Indus is major contributor of $<63 \mu \mathrm{m}$ sediment, transported in suspension as shown by

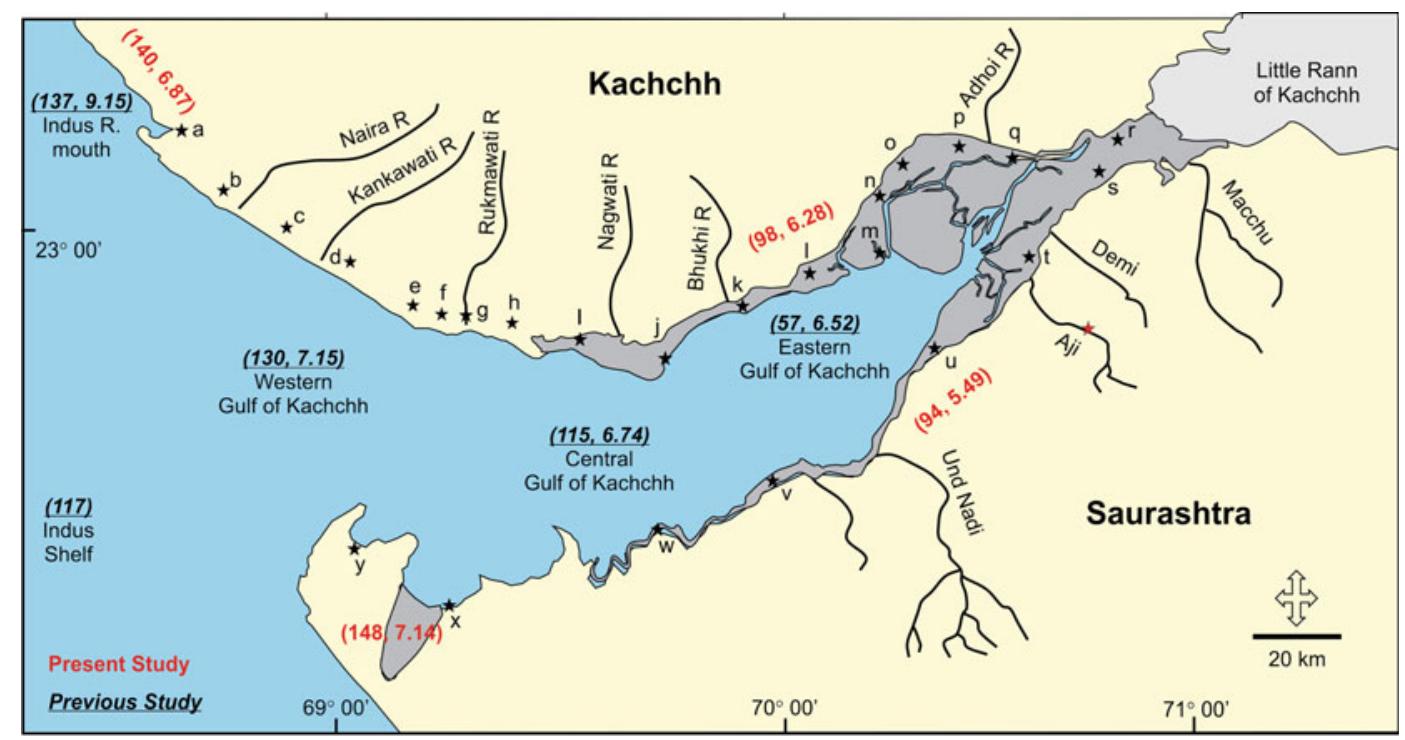

Figure 8. Spatial distribution of average elemental concentrations of $\mathrm{Rb}$ and $\mathrm{Rb} / \mathrm{Ga}$ ratio in various segments of GoK coastline from present study (in red) and previous work (in black) (after Ahmad et al. 1998; Ramaswamy et al. 2007; Limmer et al. 2012b). 


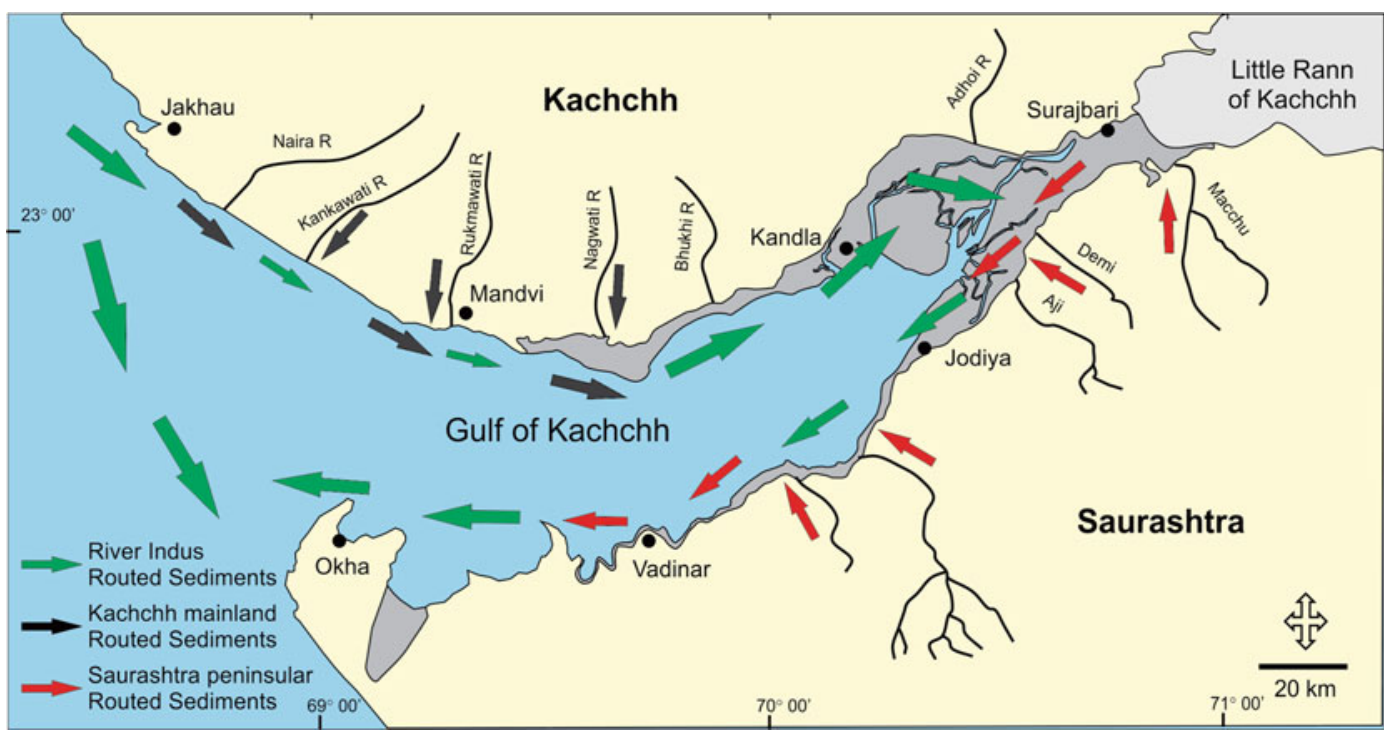

Figure 9. Sediment dispersal model for the GoK coastline showing dominance of sediment sources in various segments of GoK coastline.

clay mineralogy (dominant illite-chlorite assemblage), $\mathrm{Al}$ and $\mathrm{Rb}$ concentrations and the $\mathrm{Rb} / \mathrm{Ga}$ ratio. The suspended sediments advected from the Indus River enter the GoK from the west along the mouth on the northern coast and travelled all along the northern coast driven by long-shore currents (Kunte et al. 2003; Prizomwala et al. 2012). As this sediment reaches the central GoK the currents are deflected in a northeastern direction and it travels along mudflats of the inner GoK, where most of the suspended sediments are deposited. The residence time of suspended sediments in GoK is mostly in the mudflats of the inner GoK, which is also demonstrated by the clear water patch (low suspended sediment concentration) reported by Ramaswamy et al. (2007) along the southern coast of GoK. The currents are reversed at the head of inner GoK and continue to travel along the southern coast of GoK (Kunte et al. 2003; Prizomwala et al. 2012). The suspended sediment concentration near the southern coast of GoK is less compared to the suspended sediment concentration along central and northern coast (Ramaswamy et al. 2007). Some part of the Indus River-derived suspended sediments also travel directly southwards and can be evidenced by the illite + chlorite/smectite + kaolinite ratio which is $>2$ at the mouth of the southern coast of the GoK, as well as in the clay mineralogy, enrichment in $\mathrm{Rb}$ and $\mathrm{Rb} / \mathrm{Ga}$ ratio, in magnetic concentrations and in the magnetic mineralogy.

\subsection{The Kachchh mainland provenance}

The dominance of Kachchh mainland sediment supply can be observed in the $>63 \mu \mathrm{m}$ fraction along the northern sandy coast of the GoK towards west in heavy mineral and mineral magnetic studies (Prizomwala et al. 2013). Coastal rivers flowing from the Kachchh mainland, namely the Kankawati, Rukmawati and Kharod, act as suppliers of the hinterland load along the coastline, which was demonstrated by an increase in the concentration of diopsidic clinopyroxene and opaque heavy minerals at these river mouths. Similarly the higher concentration of magnetic minerals at these river mouths $\left(\chi_{\mathrm{LF}}=400\right.$ to $2400\left(\times 10^{-7}\right.$ $\left.\mathrm{m}^{3} \mathrm{~kg}^{-1}\right)$ ) and lower $\mathrm{Rb}$ and $\mathrm{Rb} / \mathrm{Ga}$ ratio $(31,2.17)$ also supports our suggestion that these rivers are important suppliers of sediment.

\subsection{The Saurashtra peninsular provenance}

The provenance of sediment from the Saurashtra peninsular is characterized by illite + chlorite/ smectite + kaolinite ratios that range between 0.5 and 1.0 because of the dominance of the smectitekaolinite assemblage and enrichment in mineral magnetic concentration along the southern coast of inner GoK towards the east. The inner mudflats show major increase in the clay fraction derived from the Indus River due to high sediment flux. However the southern part of the inner gulf mudflats exhibits a dominance of Deccan Trap derived clay minerals (i.e., smectite). This is contradictory to the understanding that the small coastal rivers of hinterland do not contribute sediments because of their ephemeral nature. Despite this character, these small coastal rivers contribute significant amount of sediments to the GoK coastline owing to their 'dryland' nature. 


\section{Conclusion}

The study of geomorphic assemblages, granulometry of coastal sediments, mineral magnetic studies, clay mineralogy, sediment geochemistry and heavy mineral assemblages point towards three major end members which control sedimentation along the GoK coast. These are: (1) River Indus, (2) Kachchh mainland coastal river systems and (3) Saurashtra peninsular coastal rivers. The Indus River, which is the only perennial river in the region is the major source of fine grained $(<63 \mu \mathrm{m})$ sediments to the inner gulf mudflats of the GoK coast. Although ephemeral, the coastal fluvial systems of the Kachchh mainland and the Saurashtra peninsula dominate the coarse grained $(>63 \mu \mathrm{m})$ sedimentation along the GoK coast. The northern coast of the GoK has dominant signatures of Kachchh mainland provenance and the southern coast of GoK has dominance of Saurashtra peninsular provenance. However, the Indus River is a comparatively more distant source and has a dominant provenance in the inner GoK mudflats because of its contribution to the suspended load. Proxies like clay mineralogy, mineral magnetic properties, geochemistry and heavy mineral analysis, all support the proposed provenance model. The study also highlights the sediment generation capacity of these coastal ephemeral rivers, their significance in dispersal system and their impact on processes acting along the coastline.

\section{Acknowledgements}

This is a contribution to the DST, Government of India sponsored research programme on Science of Shallow Subsurface (DST No. SR/S4/ES21/ Kachchh Window/P6). Prof L S Chamyal of the M S University of Baroda is thankfully acknowledged for constant encouragement and fruitful discussions. A critical review by anonymous reviewers and editors of the JESS has helped in significant improvement of the earlier version of the manuscript.

\section{References}

Ahmad T, Khanna P P, Chakrapani G J and Balakrishnan S 1998 Geochemical characteristics of water and sediment of the Indus River, Trans-Himalaya, India: Constraints on weathering and erosion; J. Asian Earth Sci. 16 333-346.

Alizai A, Hillier S, Clift P D and Giosan L 2012 Clay mineral variations in Holocene terrestrial sediments from the Indus basin: A response to SW Asian monsoon variability; Quat. Res. 77(3) 368-381.

Babu M T, Vethamony P and Desa E 2005 Modelling tide-driven currents and residual eddies in the Gulf of
Kachchh: A marine environmental planning perspective; Ecol. Model. 184(2-4) 299-312.

Basavaiah N 2011 Geomagnetism: Solid Earth and Upper Atmosphere Perspectives (Dordrecht, The Netherlands: Springer), 410p.

Biscaye P E 1965 Mineralogy and sedimentation of recent deep sea clay in Atlantic ocean and adjacent seas and oceans; Geol. Soc. Am. Bull. 76 803-832.

Biswas S K 1993 Geology of Kutch; K.D. Malaviya Institute of Petroleum Exploration, Dehradun, 2 450p.

Castelltort S and Van Den Driessche J 2003 How plausible are high-frequency sediment supply-driven cycles in the stratigraphic record?; Sedim. Geol. 157 3-13.

Chauhan O S 1994 Influence of macrotidal environment on shelf sedimentation, Gulf of Kachchh, India; Cont. Shelf Res. 14 1477-1493.

Chauhan O S, Jayakumar S, Menezes A A, Suneethi J, Shradha N, Rajawat A S, Nayak S R, Ramanamurthy M V and Subramanian B R 2004 Tidal currents as feeders of the river Indus flux into the macrotidal Gulf of Kachchh, India; 3rd Indian National Conference on Harbour and Ocean Engineering, NIO, Goa, pp. $174-183$.

Chauhan O S, Jayakumar S, Menezes A A, Rajawat A S and Nayak S R 2006 Anomalous inland influx of River Indus, Gulf of Kachchh, India; Marine Geol. 229 91-100.

Folk R L 1974 Petrology of sedimentary rocks; Hemphill Publishing Co. Texas, 184p.

Garzanti E and Ando S 2007 Heavy mineral concentration in modern sands: Implications for provenance interpretation; Dev. Sedim. 58 517-545.

Garzanti E, Vezzoli G, Andó S, Paparella P and Clift P 2005 Petrology of Indus River sands: A key to interpret erosion history of the western Himalayan Syntaxis; Earth Planet. Sci. Lett. 229 287-302.

Giosan L, Constantinescu C, Clift P D, Tabrez A R, Danish M and Inam A 2006 Recent morphodynamics of Indus delta shore and shelf; Marine Geol. 26(14) 1668-1684, doi: 10.1016/j.csr.2006.05.009.

Goodbred S L 2003 Response of Ganga dispersal system to climate change: A source-to-sink view since the last interstade; Sedim. Geol. 162 83-104.

Hashimi N H, Nair R R and Kidwai R M 1978 Sediments of Gulf of Kachchh - A high energy tide dominated environment; Indian J. Marine Sci. 7 1-7.

Horng C S and Huh C A 2011 Magnetic properties as tracers for source-to-sink dispersal of sediments: A case study in the Taiwan Strait; Earth Planet. Sci. Lett., doi: 10.1016/j.epsl.2011.07.002.

Jiang F, Li A and Li T 2011 Sediment pathway of East China Sea inferred from an R-mode factor analysis of surface sediments in Okinawa trough; Quat. Int. 230(1-2) 13-20.

Kar A 1993 Neotectonic influence on morphological variations along coastline of Kachchh, India; Geomorphology 8 199-219.

Kessarkar P M, Rao V P, Ahmad S M and Badu B A 2003 Clay minerals and $\mathrm{Sr}-\mathrm{Nd}$ isotopes of the sediments along the western margin of India and their implication for sediment provenance; Marine Geol. 202 55-69.

Kolla V, Henderson L and Biscaye P E 1976 Clay mineralogy and sedimentation in the western Indian ocean; Deep Sea Research and Oceanagraphic abstracts 23(10) 949-961.

Kuehl S A, Brunskill G J, Burns K A, Fugate D C, Kniskern T and Meneghini L 2004 Nature of sediment dispersal off the Sepik River, Papua New Guinea: Preliminary sediment budget and implications for margin processes; Cont. Shelf Res. 24(19) 2417-2429. 
Kunte P D, Wagle B G and Sugimori Y 2003 Sediment transport and depth variation study of Gulf of Kutch using remote sensing; Intl. J. Rem. Sen. 24(11) 2253-2263.

Lepland A and Stevens R L 1996 Mineral magnetic and textural interpretations of sedimentation in the Skagerrak, eastern North Sea; Marine Geol. 135 51-64.

Limmer D, Köhler C, Hillier S, Mauqoy D, Alizai A, Sothcott J, Giosan L, Ponton C, Tabrez A and Clift P D 2012a Temporal changes in physical properties and mineralogy of Holocene to Recent sediments from the Western Indus Shelf, Northern Arabian Sea; Marine Geol. 326-328 101-115.

Limmer D R, Boening P, Giosan L, Ponton C, Köhler C M, Cooper M J, Tabrez A R and Clift P D 2012b Geochemical record of Holocene to recent sedimentation on the western Indus continental shelf, Arabian Sea; Geochem. Geophys. Geosyst. 13(Q01008), doi: 10.1029/ 2011GC003845.

Liu S, Zhang W, He Q, Li D, Liu H and Yu L 2010 Magnetic properties of East China sea shelf sediments off Yangtze estuary: Influence of provenance and particle size; Geomorphology 119 212-220.

Maher B A, Watkins S J, Brunskill G, Alexander J and Fielding C R 2009 Sediment provenance in a tropical fluvial and marine context by magnetic 'fingerprinting' of transportable sand fractions; Sedimentology 56 841-861.

Mange M A and Maurer H F W 1991 Heavy Minerals in Colour; Chapman and Hall, London 1 160p.

MARGINS Office 2003 Source-to-Sink. NSF MARGINS Program Science Plans 2004, Lamont-Doherty Earth Observatory of Columbia University, New York, September 2003, 170p.

Maurya D M, Thakkar M G, Patidar A K, Bhandari S, Goyal B and Chamyal L S 2008 Late Quaternary geomorphic evolution of coastal zone of Kachchh, western India; J. Coast. Res. 24(3) 746-758.

Milliman J D, Quraishee G S and Beg M A A 1982 Sediment discharge from the Indus River to the ocean: Past, present and future; In: Marine Geology and Oceanography of Arabian Sea and Coastal Pakistan (eds) Haq B U and Milliman J D, Van Nostrand Reinhold, New York, pp. $65-70$.

Nair R R, Hashimi N H and Rao V P 1982 On the possibility of high velocity tidal streams as dynamic barrier to longshore sediment transport: Evidence from continental shelf off the Gulf of Kachchh, India; Marine Geol. 47 77-86.

Nechaev V P and Isphording W C 1993 Heavy-mineral assemblages of continental margins as indicators of plate-tectonic environments; J. Sedim. Res. 63(6) 1110-1117.

Oldfield F and Yu L 1994 The influence of particle size variations on the magnetic properties of sediments from the north-eastern Irish Sea; Sedimentology 41 1093-1108.

Petschick R, Kuhn G and Gingele F 1996 Clay mineral distribution in surface sediments of south Atlantic: Sources, transport and relation to oceanography; Marine Geol. $130203-229$.

Pettijohn F J, Potter P E and Siever R 1987 Sand and Sandstones; 2nd edn, Springer-Verlag, New York, 553p.

Prizomwala S P, Shukla S B and Bhatt N 2010 Geomorphic assemblage of the Gulf of Kachchh coast, western India: Implication in understanding the pathways of coastal sediments; Zeitschrift fur Geomorphologie 54(1) 31-46.
Prizomwala S P, Shukla S B and Bhatt N 2012 Distribution of Indus born mica along Gulf of Kachchh coast: Implications in understanding offshore dynamics; J. Geol. Soc. India 79 557-562.

Prizomwala S P, Shukla S B, Basavaiah N and Bhatt N 2013 Provenance discrimination studies on sediments of SW Kachchh coast, western India: Insights from heavy mineral and mineral magnetic analysis; J. Coast. Res. 29(1) $52-60$.

Prizomwala S P, Bhatt N and Basavaiah N Provenance discrimination and source-to-sink studies from a dryland fluvial regime: An example from Kachchh, western India; Int. J. Sedim. Res. (in press).

Ramaswamy V, Nagender N B, Vethamony $\mathrm{P}$ and Illangovan D 2007 Source and dispersal of suspended sediment in macro-tidal Gulf of Kachchh; Marine Pollut. Bull. 54 708-719.

Rao V P and Rao B R 1995 Provenance and distribution of clay minerals sediments in sediments of the western continental shelf and slope of India; Cont. Shelf Res. 15(14) $1757-1771$.

Shetye S R 1999 Tides in the Gulf of Kachchh, India; Cont. Shelf Res. 19 1771-1782.

Shukla S B, Prizomwala S P, Ukey V, Bhatt N and Chamyal L S 2010 Coastal geomorphology and tsunami hazard scenario along the Kachchh coast, western India; Indian J. Geo-Marine Sci. 39(4) 549-556.

Staubwasser M and Sirocko F 2001 On the formation of laminated sediments on the continental margin off Pakistan: The effects of sediment provenance and sediment redistribution; Marine Geol. 172 43-56.

Syvitski J P M, Kettner A J, Correggian A and Nelson B W 2005 Distributary channels and their impact on sediment dispersal; Marine Geol. 222-223 75-94.

Vethamony P, Reddy G S, Babu M T, Desa E and Sudheesh K 2005 Tidal eddies in a semi-enclosed basin: A model study; Marine Environ. Res. 59 519-532.

Vethamony P, Babu M T, Ramanamurty M V, Saran A K, Joseph A, Sudheesh K, Padgaonkar R S and Jayakumar S 2007 Thermohaline structure of an Inverse Estuary - the Gulf of Kachchh: Measurements and model simulations; Marine Pollut. Bull. 54(6) 697-707.

Vora K H, Chauhan O S and Rao B R 1987 Some geological processes in the macro-tidal regime of Gulf of Kachchh, Northwest coast of India; Indian J. Marine Sci. 16 230-234.

Wang Y, Dong H, Li G, Zhang W, Oguchi T, Bap M, Jiang H and Bishop M 2010 Magnetic properties of muddy sediments on the northeastern continental shelves of China: Implication for provenance and transportation; Marine Geol. 274 107-119.

Wasson R J 2003 A sediment budget for the GangaBrahmaputra catchment; Curr. Sci. 84(8) 1041-1047.

Worm H-U 1998 On the superparamagnetic-stable single domain transition for magnetite, and frequency dependency of susceptibility; Geophys. J. Int. 133 201-206.

Yang S Y, Jung H S, Lim D I and Li C X 2003 A review on provenance discrimination of sediments in Yellow sea; Earth Sci. Rev. 63 93-120.

Yang S, Wang Z, Guo Y, Li C and Cai J 2009 Heavy mineral composition of Changjiang (Tangtze river) sediments and their provenance tracing implication; J. Asian Earth Sci. 35 56-65. 